\title{
Ex vivo generation of myeloid-derived suppressor cells that model the tumor immunosuppressive environment in colorectal cancer
}

\author{
Inès Dufait ${ }^{1,2}$, Julia Katharina Schwarze ${ }^{1}$, Therese Liechtenstein $^{3,4}$, Wim Leonard ${ }^{1}$, \\ Heng Jiang ${ }^{1}$, David Escors ${ }^{3,4}$, Mark De Ridder ${ }^{1, *}$ and Karine Breckpot ${ }^{2, *}$ \\ ${ }^{1}$ UZ Brussel, Department of Radiotherapy, Vrije Universiteit Brussel, Brussels, Belgium \\ ${ }^{2}$ Laboratory of Molecular and Cellular Therapy, Vrije Universiteit Brussel, Brussels, Belgium \\ ${ }^{3}$ Navarrabiomed-Fundaçion Miguel Servet, Immunomodulation group, Pamplona, Spain \\ ${ }^{4}$ Division of Infection and Immunity, University College London, London, UK \\ * These senior authors contributed equally to this work \\ Correspondence to: Karine Breckpot, email: kbreckpo@vub.ac.be \\ Keywords: MDSC, CRC, arginase-1, inducible nitric oxide synthase, GM-CSF \\ Received: February 18, $2015 \quad$ Accepted: March 11, $2015 \quad$ Published: March 29, 2015
}

This is an open-access article distributed under the terms of the Creative Commons Attribution License, which permits unrestricted use, distribution, and reproduction in any medium, provided the original author and source are credited.

\section{ABSTRACT}

Myeloid-derived suppressor cells (MDSC) are a heterogeneous population of cells that accumulate in tumor-bearing subjects and which strongly inhibit anticancer immune responses. To study the biology of MDSC in colorectal cancer (CRC), we cultured bone marrow cells in conditioned medium from CT26 cells, which are genetically modified to secrete high levels of granulocyte-macrophage colonystimulating factor. This resulted in the generation of high numbers of $\mathrm{CD}_{11 \mathrm{~b}^{+}} \mathrm{Ly}^{6} \mathrm{G}^{+}$

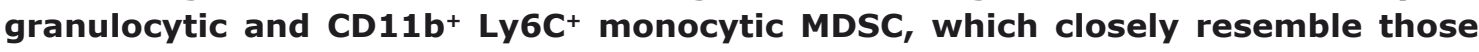
found within the tumor but not the spleen of CT26 tumor-bearing mice. Such MDSC potently inhibited T-cell responses in vitro, a process that could be reversed upon blocking of arginase-1 or inducible nitric oxide synthase (iNOS). We confirmed that inhibition of arginase-1 or iNOS in vivo resulted in the stimulation of cytotoxic T-cell responses. A delay in tumor growth was observed upon functional repression of both enzymes. These data confirm the role of MDSC as inhibitors of T-cell-mediated immune responses in CRC. Moreover, MDSC differentiated in vitro from bone marrow cells using conditioned medium of GM-CSF-secreting CT26 cells, represent a valuable platform to study/identify drugs that counteract MDSC activities.

\section{INTRODUCTION}

Colorectal cancer (CRC) is characterized by the infiltration with various immune cell types [1]. The infiltration of CRC with $\mathrm{CD} 8^{+}$cytotoxic $\mathrm{T}$ lymphocytes (CTLs) has been correlated to a favorable prognosis $[2,3]$. However, these CTLs are largely dysfunctional, as a result of their interaction with myeloid-derived suppressor cells (MDSC). Therefore, it was suggested that the absence of MDSC infiltration might serve as a better prognostic biomarker [4, 5]. Moreover, it was suggested that pharmacologic blockade of MDSC represents an attractive strategy to treat CRC.
Experimental CRC models such as those based on murine CT26 cells are often used to evaluate the growing list of anti-MDSC agents. This model is a valuable substitute for human CRC as, similarly to CRC in human patients, it is infiltrated with CTLs that are rendered inactive due to immunosuppression exerted by MDSC [6].

In mice, MDSC represent a heterogeneous population comprised of immature myeloid cells. These are characterized by the expression of CD11b and Gr-1, and lack markers specific for monocytes, macrophages and dendritic cells. MDSC can be subdivided in two subsets, namely monocytic and granulocytic MDSC on the basis of Ly6C-Ly6G expression profiles. While monocytic MDSC express low (or absent) Ly6G levels, granulocytic MDSC 
express high levels of Ly6G [7]. Various tumor-derived factors have been described to induce MDSC, these include but are not limited to granulocyte macrophagecolony stimulating factor (GM-CSF), macrophage-colony stimulating factor (M-CSF), prostaglandin E2 (PGE2), vascular endothelial growth factor (VEGF), stem cell factor (SCF), interleukin-6 (IL-6), IL-10 and IL-1 $\beta$ [7, 8]. Importantly, MDSC use a plethora of mechanisms to suppress antitumor immunity. One of these is the depletion of L-arginine mediated by arginase-1 (arg-1) and inducible nitric oxide synthase (iNOS), expressed in MDSC. L-arginine depletion was shown to limit T-cell proliferation and T-cell receptor signaling, and it is still considered the major mechanism through which MDSC mediate T-cell dysfunction $[9,10]$.

The ample evidence on the role of MDSC in cancers such as CRC has instigated research into the use of existing drugs as well as the development of novel drugs to deplete MDSC, block or revert their immunosuppressive activity. For example, chemotherapy drugs which have been shown to deplete MDSC include 5-fluororacil (5FU) [11], gemcitabine [12, 13] and docetaxel [14]. In these drug discovery studies, MDSC derived from the spleen of tumor-bearing animals are most commonly used solely because they can be obtained in large numbers. However, splenic MDSC are phenotypically and functionally different from MDSC derived from within the tumor [15, 16]. Consequently, to ensure reliability and potency of novel MDSC-targeting drugs, they should be evaluated on tumor-derived rather than splenic MDSC. However, studying tumor-derived MDSC poses the technical challenge of obtaining sufficient number of cells at high purity from a limited number of tumor-bearing animals [17]. To circumvent this conundrum, researchers have evaluated various in vitro culture systems to obtain MDSC that closely resemble those found within the tumor. First of all, immortalized MDSC cell lines such as MSC-1 and MSC-2, were constructed using retroviral transduction but lack the distinct marker of MDSC, namely Gr-1 [18]. However, other ex vivo procedures starting from bone marrow cells were characterized by a low differentiation efficiency (up to $40 \%$ ), resulting in only a limited amount of MDSC-like cells [19-27]. We recently developed an ex vivo system to efficiently differentiate bone marrow cells into MDSC [27, 28]. Herein conditioned medium from tumor cells that were transduced with lentiviral vectors encoding GM-CSF is used to differentiate bone marrow cells. A proof-of-concept on the value of this strategy to obtain large amounts of MDSC that resemble those found within B16 melanomas was delivered [28].

In the current study, we demonstrate that the ex vivo culture procedure is readily applicable to $\mathrm{CRC}$ and could be used as a predictive model as such facilitating the search for novel anti-MDSC drugs. Here we thoroughly characterize these ex vivo differentiated CRC-specific MDSC, demonstrate that their functions could be counteracted by arg-1 and iNOS inhibitors and that these treatments possess therapeutic activities in vivo.

\section{RESULTS}

\section{High levels of GM-CSF are required to efficiently differentiate bone marrow cells to MDSC}

CRC expands MDSC in vivo, which seem to contribute to tumor staging and poor prognosis [4, 2931]. Usually, a large tumor burden is required to divert physiological myeloid differentiation towards MDSC expansion, possibly due to local and systemic GMCSF accumulation. As we aimed to develop an in vitro culture system to differentiate bone marrow cells to MDSC resembling those found within CRC tumors, we first evaluated using ELISA whether the CRC cell line CT26 produced high levels of GM-CSF. CT26 tumor cells produced barely any GM-CSF (Fig. 1A). Therefore, we decided in analogy to our previous study on in vitrogenerated melanoma MDSC [28], to transduce CT26 tumor cells with lentiviral vectors encoding GM-CSF. This resulted in secretion of high levels of GM-CSF (Fig. 1A). To examine whether the secreted GM-CSF was biologically active, GM-CSF-dependent FDCP-1 cells were labeled with CFSE and consequently cultured in the presence or absence of recombinant murine GMCSF, as well as in conditioned medium (CM) of CT26GM-CSF and CM of non-modified CT26 tumor cells. In this assay the proliferation of FDCP-1 cells incubated in recombinant GM-CSF was comparable to that of FDCP-1 cells incubated with CM of CT26-GM-CSF (Fig. 2B-2C). This $\mathrm{CM}$ was subsequently used to culture bone marrow cells, demonstrating that after 6 days of culture, cell yields were consistently higher in the high GM-CSF condition (Fig. 1D). Moreover, the majority of these cells expressed CD11b. This was not the case in cultures with CM of non-modified CT26 tumor cells (Fig. 1E). To identify the concentration of GM-CSF necessary to generate $\mathrm{CD} 11 \mathrm{~b}^{+}$cells, we used CM of non-modified CT26 tumor cells supplemented with different concentrations of recombinant GM-CSF to culture bone marrow cells. High percentages of $\mathrm{CD}_{11} \mathrm{~b}^{+}$cells were generated in the presence of recombinant GM-CSF, without significant differences when using relative high $(320 \mathrm{ng} / \mathrm{ml})$ or low GM-CSF concentrations (20 ng/ml) (Fig. 1E). However, a significant difference was observed in the yield of CD11b cells between the conditions where recombinant GM-CSF or CM of transduced CT26 tumor cells was used (Fig. 1F). Since the yield and purity of CD11b ${ }^{+}$cells was highest after differentiation in CM from CT26-GMCSF cells (Fig. 2A), we continued with these culture conditions. MDSC are known to be a very heterogeneous population of cells but can be generally divided into a 
monocytic $\left(\mathrm{Ly}_{6 \mathrm{C}}{ }^{+}\right)$and a granulocytic $\left(\mathrm{Ly}_{6 \mathrm{G}}{ }^{+}\right)$subset. We examined the appearance of these subsets in the generated $\mathrm{CD}_{11} \mathrm{~b}^{+}$population (Fig. 2B). The ratio of the different subsets in the in vitro system coincides with the in vivo situation. Next, we examined their suppressive capacity as it is widely accepted that functionality and more specifically suppression of T-cell responses, is the single most important marker to identify MDSC. We showed that sorted $\mathrm{CD} 11 \mathrm{~b}^{+} \mathrm{Ly}_{6 \mathrm{C}}^{+}$as well as $\mathrm{CD} 11 \mathrm{~b}^{+} \mathrm{Ly}_{6 \mathrm{G}}^{+}$cells (Fig. 2C) had a high T-cell suppressive capacity (Fig. 2D-
2E). Consequently, the $\mathrm{CD} 11 \mathrm{~b}^{+}$cells obtained through the culture of bone marrow cells in CM of CT26-GM-CSF tumor cells could be considered as MDSC.

\section{A}
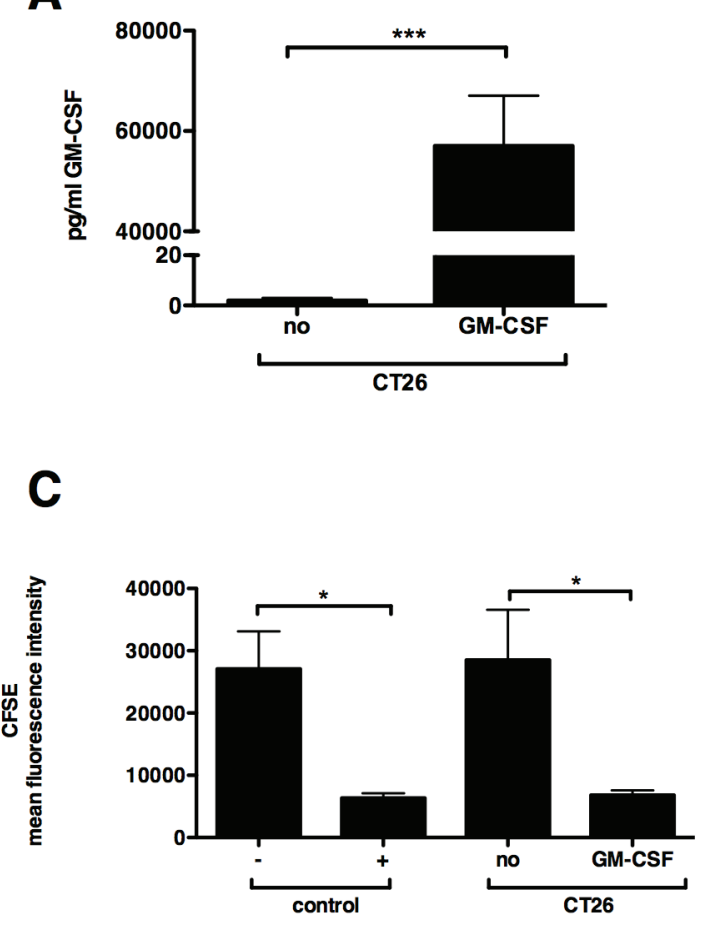

E

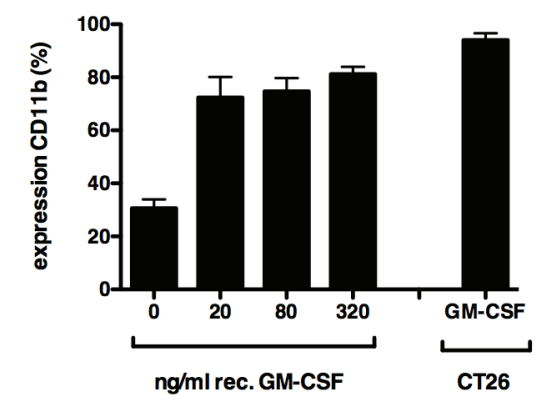

B

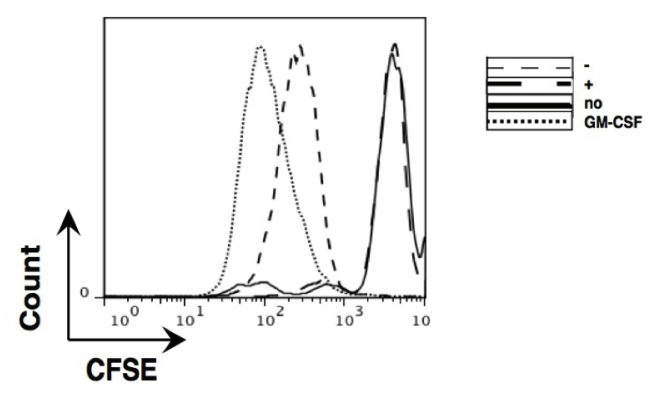

D

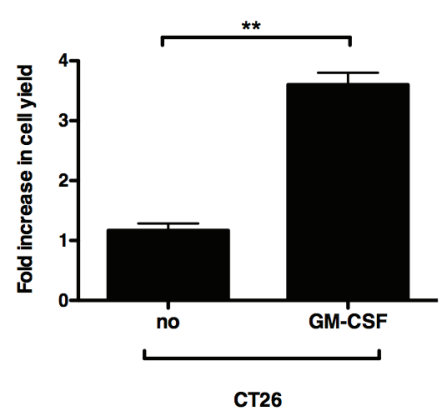

F

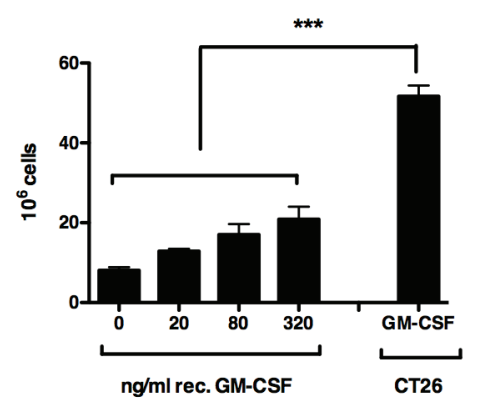

Figure 1: Ex vivo myelopoiesis can differentiate bone marrow cells into myeloid cells in the presence of GM-CSF. (A) Graph representing murine GM-CSF content as measured by ELISA present in the CM of wildtype (no) and transduced (GM-CSF) CT26 tumor cells. (B) Representative histogram showing proliferation, as measured by dilution of CFSE, of the GM-CSF dependent FDCP-1 cells incubated for 72 hours in DMEM with $(+)$ or without (-) recombinant GM-CSF $(20 \mathrm{ng} / \mathrm{ml})$ or incubated in CM of non-modified (no) and transduced CT26 tumor cells (GM-CSF). (C) Summarizing graph showing the mean fluorescence intensity (MFI) of CFSE positive FDCP-1 cells, a lower MFI representing strong proliferation of the FDCP-1 cells. (D) Fold increase in bone marrow cells incubated for 6 days in CM. (E) Expression of CD11b by bone marrow cells after a 6-day incubation period in CM. (F) Cell yield after 6 days incubation of $10 \times 10^{6}$ bone marrow cells in CM. Mean of at least 3 experiments $+/-$ SEM is shown in all graphs. Number of asterisks in the figures indicates the level of statistical significance as follows: ${ }^{*}, p<0.05 ; * *, p<0.01 ; * * *, p<0.001$. 
A

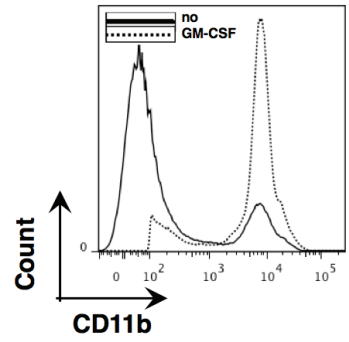

B

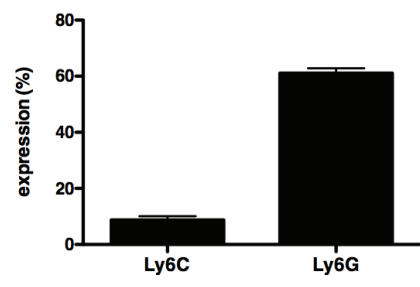

C
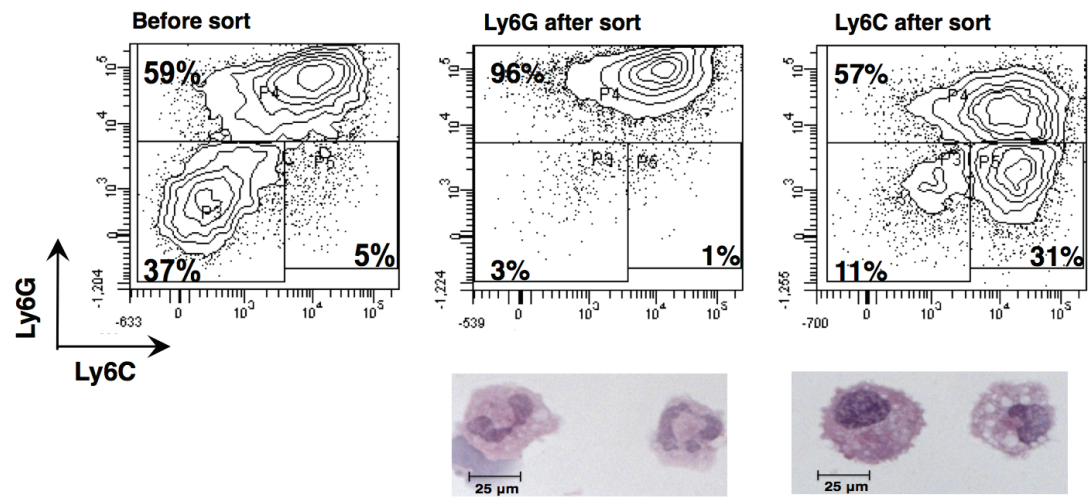

D

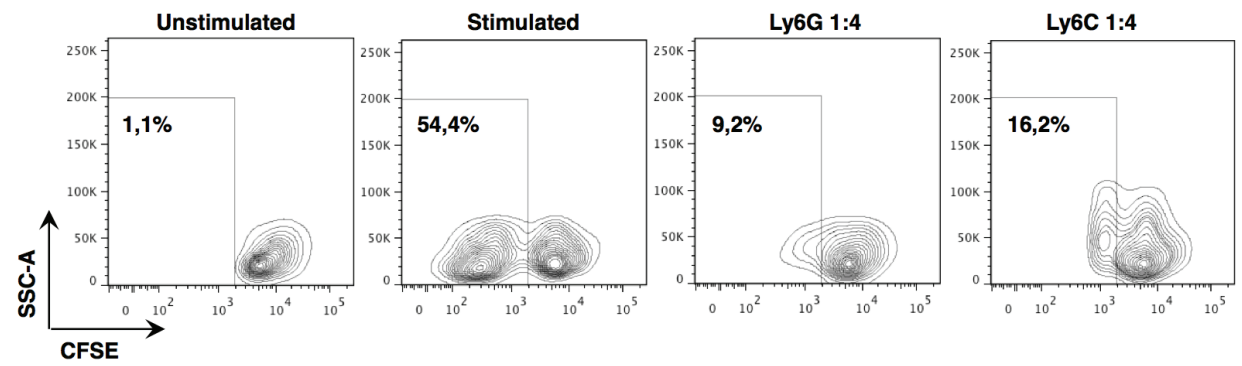

E
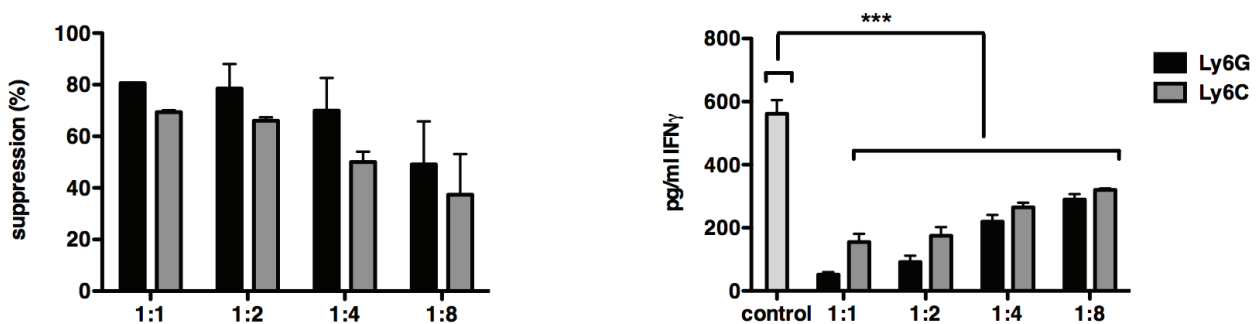

Figure 2: Differentiated bone marrow cells possess strong suppressive capacities and can be subdivided into both MDSC subsets. (A) Expression of CD11b by bone marrow cells after a 6-day incubation period in CM as measured by flow cytometry. (B) Summarizing graph of ratio of MDSC subsets (C) Flow cytometry contour plots of in vitro MDSC before and after MACS sort. Underneath the contour plots of the sorted MDSC, representative pictures showing the morphology of these subsets are depicted. Pictures were taken with a light microscope at 64 times magnification. (D) Representative experiment showing suppression of CD ${ }^{+} \mathrm{T}$ cells by sorted in vitro MDSC (1:4 ratio MDSC to T cell). (E) The graph on the left represents the proliferation inhibition of CD3/CD28-activated $\mathrm{CD} 8^{+} \mathrm{T}$ cells (ratio MDSC to T cell as indicated in the graph). The graph on the right shows changes in IFN- $\gamma$ secretion measured during the same experiment. Control represents T cells incubated without MDSC. Mean of at least 3 experiments $+/-$ SEM is shown in all graphs. Number of asterisks in the figures indicates the level of statistical significance as follows: ***, $p<0.001$. 


\section{In vitro-generated MDSC closely resemble MDSC found within both wild-type and GM-CSF- producing CT26 tumors}

To examine whether the in vitro-generated MDSC resembled those found within CT26 tumors, we then compared their function and phenotype with MDSC isolated from the spleen and tumor of CT26-bearing mice. We also isolated MDSC from mice bearing CT26GM-CSF tumor cells to examine the effect of GM-CSF overexpression in vivo. We observed that mice bearing CT26-GM-CSF tumors showed splenomegaly (Fig. 3A3B) and moreover, that CT26-GM-CSF tumors hardly progressed after day 12 , although the growth of unmodified CT26 or CT26-GM-CSF tumor cells initially followed a similar pattern (Fig. 3C). This decline in tumor growth was not correlated with the presence of tumor-specific T-cell responses as evaluated by ELISPOT (data not shown). In addition, evaluation of the T-cell suppressive activity of bulk (granulocytic and monocytic) MDSC showed that in vitro-generated MDSC, as well as MDSC derived from the spleen or tumor were highly capable of suppressing T-cell proliferation in a 1:1 MDSC to T cell ratio. No differences in functionality were observed between MDSC derived from CT26- and CT26-GM-CSF bearing mice (Fig. 3D). The CT26-GM-CSF tumors showed high infiltration of $\mathrm{CD}^{2} 5^{+}$cells, which correlated with a significant increase in $\mathrm{CD}_{11} \mathrm{~b}^{+}$but not $\mathrm{CD} 11 \mathrm{c}^{+}$or $\mathrm{F} 4 / 80^{+}$cells (Fig. $3 \mathrm{E}-3 \mathrm{~F}$ ).

Similar to previous reports $[15,16]$, we observed that MDSC found within the spleen (irrespective of the level of GM-CSF expression by CT26 cells) showed significant differences to MDSC found within the tumor. More specifically, a lower expression of CD80 and PD-L1 of splenic-MDSC was observed when compared to tumorinfiltrating MDSC (Fig. 3G). This data again confirmed the observation that MDSC accumulating in the spleen are distinct and different from tumor MDSC. Moreover, MDSC found within the spleen of mice bearing CT26GM-CSF cells showed lower expression of MHC II when compared to MDSC obtained from tumors as well as the spleen of mice bearing non-modified CT26 cells. In contrast, lower expression of Sca-1 was observed in the granulocytic MDSC subset obtained from the tumor in comparison to the spleen, while opposite results were obtained for the monocytic MDSC subset. Importantly, the expression of MHC II, PD-L1 CD80 and Sca-1 was not significantly different on MDSC isolated from the tumor of non-modified CT26 cells when compared to CT26-GM-CSF tumors (Fig. 3G). The phenotype of in vitro-generated MDSC showed that they were closely related to the MDSC found within tumors but not spleen, as they expressed high levels of MHC II, PD-L1 and CD80 and low levels of Sca-1 (Fig. 3G). These results indicate that although high GM-CSF secretion impacts on the percentage and to a lesser extent phenotype of in vivo differentiated MDSC, the MDSC-T-cell suppressive activity is the same as found in mice bearing non-modified CT26 tumor cells. Moreover, these results show that our in vitro-generated MDSC phenotypically and functionally resemble the MDSC found within the tumor.

\section{The in vitro-generated MDSC are a reliable model to predict the outcome of MDSC-modulating drugs}

A key aim of this study was to prove that the in vitro-generated MDSC can be used as a platform to predict the outcome of anti-MDSC drugs. In the literature, it is described that MDSC-mediated L-arginine depletion by the expression of arg-1 and iNOS, plays a major role in their T-cell suppressive capacity. Therefore, we chose inhibitors of arg-1 and iNOS as ideal candidates to test the predictive value of our in vitro MDSC-platform. Interestingly, arg- 1 expression was high in tumor and in vitro-generated MDSC (both monocytic and granulocytic subsets) but not in splenic MDSC (Fig. 4A).

Similar iNOS expression was observed in the in vitro-generated and tumor $\mathrm{CD} 11 \mathrm{~b}^{+} \mathrm{Ly} 6 \mathrm{G}^{+}$granulocytic MDSC (Fig. 4A). iNOS expression was lower in in vitrogenerated and tumor $\mathrm{CD}_{11} \mathrm{~b}^{+} \mathrm{Ly} 6 \mathrm{C}^{+}$monocytic MDSC compared to their granulocytic counterparts, but still expressed to a higher extent then in splenic MDSC (Fig. 4A). These results confirm that the in vitro-generated MDSC closely resemble those found within CT26 tumors. To evaluate the extent to which arg-1 and iNOS contribute to the suppressive capacity of the in vitro MDSC, we performed an in vitro T-cell suppression assay with sorted $\mathrm{CD} 11 \mathrm{~b}^{+} \mathrm{Ly}_{6 \mathrm{G}}^{+}$and $\mathrm{CD} 11 \mathrm{~b}^{+} \mathrm{Ly}_{6 \mathrm{C}^{+}} \mathrm{MDSC}$ in the presence or absence of Nor-NOHA, an arg-1 inhibitor, and $\mathrm{AG}$, an iNOS inhibitor. We showed that both the T-cell proliferation and IFN- $\gamma$ production by the T cells was enhanced in the presence of these inhibitors (Fig 4B). These results confirmed the previously published role of arg-1 and iNOS in the T-cell suppressive activity of MDSC $[7,32]$ and suggest that the in vitro-generated CRCspecific MDSC are similar to MDSC obtained from CRC tumors. To evaluate the predictive value of $\mathrm{CRC}$-specific MDSC, this was further confirmed in vivo, in which CT26bearing mice were treated with Nor-NOHA or the specific iNOS inhibitor, $1400 \mathrm{~W}$, as the only treatment. We showed that treatment with either one of both inhibitors resulted in a CT26-specific cytotoxic immune response (Fig. 4C4D). These data suggested that inhibition of arg-1 or iNOS enabled $\mathrm{CD}^{+}$cytotoxic $\mathrm{T}$ cells to escape the MDSCmediated immune suppression, although overall survival of treated groups was not significantly prolonged (Fig. $4 \mathrm{E})$. Moreover, a delay in tumor growth was observed as long as both inhibitors were administered (Fig. 4F). Comparison of the $\mathrm{CD}^{+}$T-cell infiltration of tumors of non-treated mice or mice treated with Nor-NOHA 
A

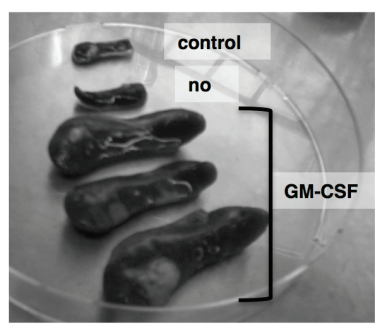

C

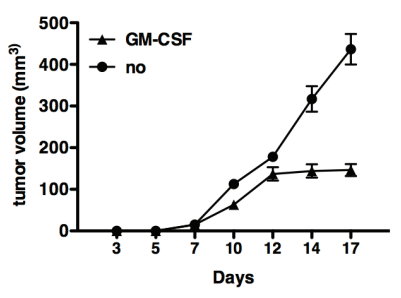

$\mathbf{E}$

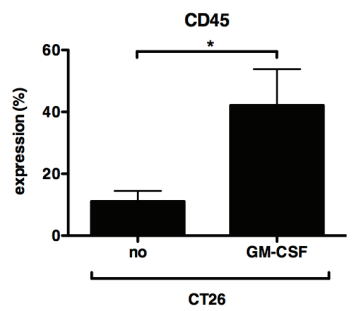

G
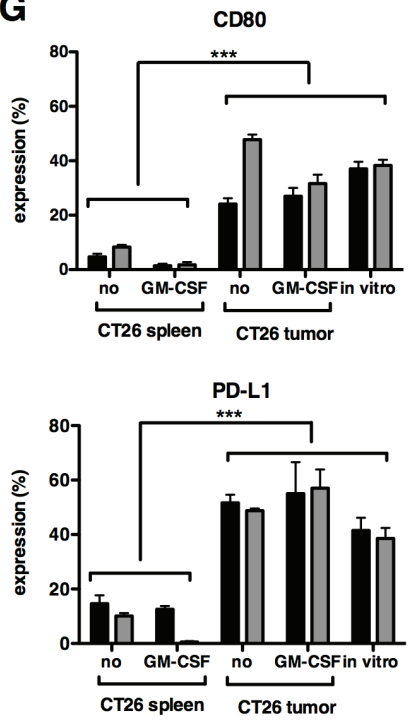

B

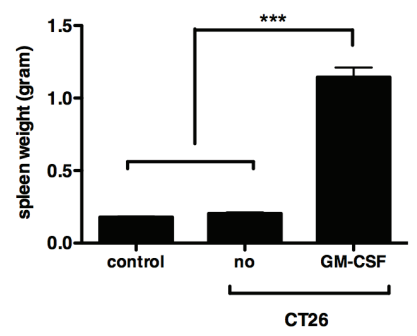

D

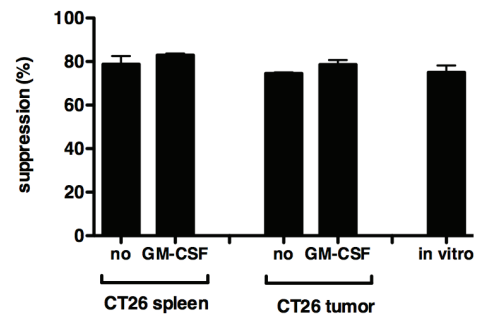

$\mathbf{F}$

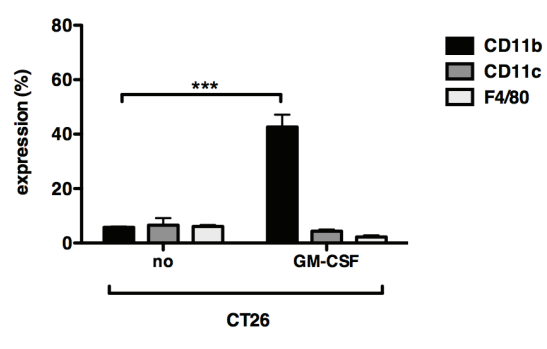

MHC II
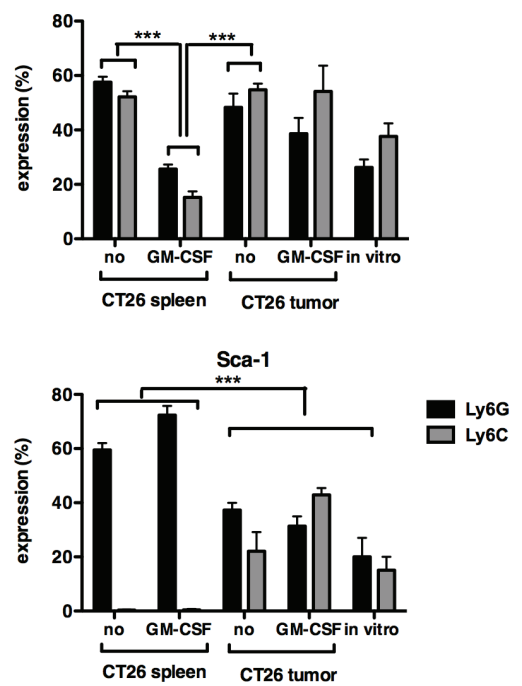

Figure 3: In vitro-generated MDSC closely resemble tumor-MDSC but not splenic-MDSC. (A) Photograph of spleen of naive mice (control), CT26- (no) and CT26-GM-CSF (GM-CSF)-bearing mice at a tumor size of approximately 5 by $6 \mathrm{~mm}$. (B) Summarizing graph showing spleen weight. (C) Tumor growth curve of CT26 versus CT26-GM-CSF-bearing mice. Day 1 represents the day of tumor injection. (D) Graph showing the proliferation inhibition of CD3/CD28-activated CD8 ${ }^{+} \mathrm{T}$ cells with bulk MDSC (1:1 MDSC to T cell ratio). (E) Summarizing graph showing CD45 infiltration in the tumor of CT26- versus CT26-GM-CSF-bearing mice. (F) Summarizing graph showing CD11b, CD11c and F4/80 content in the tumor of CT26- versus CT26-GM-CSF-bearing mice. (G) Summarizing graphs of different surface markers (CD80, MHC II, PD-L1 and Sca-1) present on MDSC, derived from spleen, tumor or in vitro-generated. Expression showed in the granulocytic (Ly6G) and monocytic (Ly6C) subset separately. Mean of at least 3 experiments $+/$ - SEM is shown in all graphs. Number of asterisks in the figures indicates the level of statistical significance as follows: *, $p<0.05 ; * * *$, $p<0.001$. 


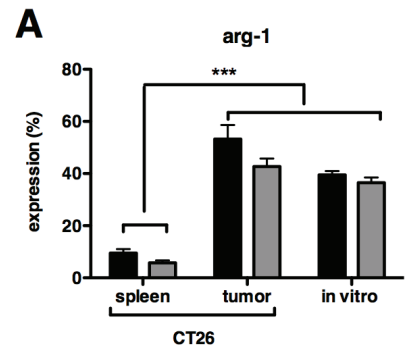

в

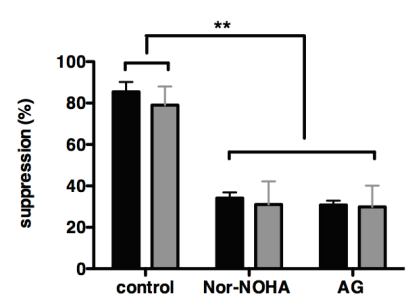

C

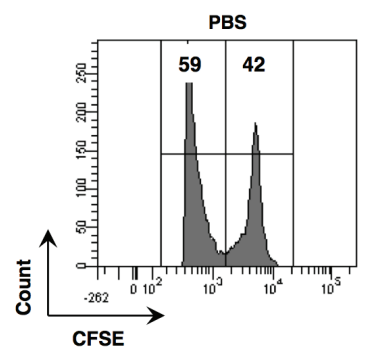

D

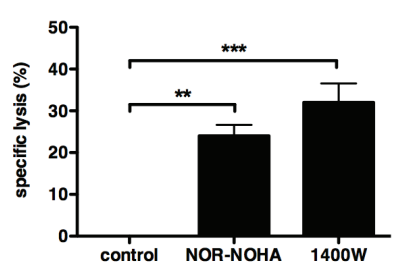

$\mathbf{F}$

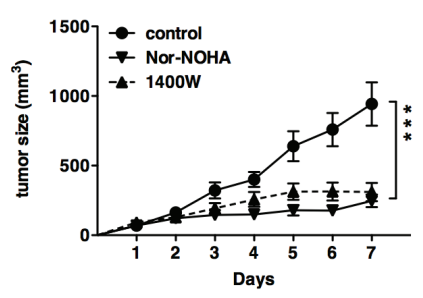

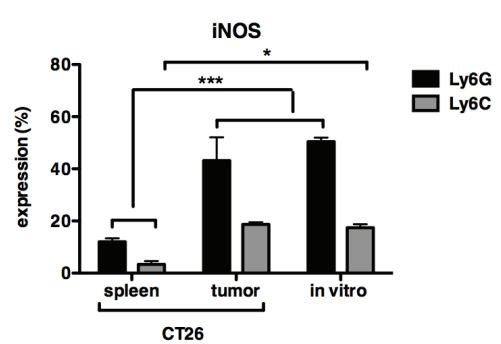
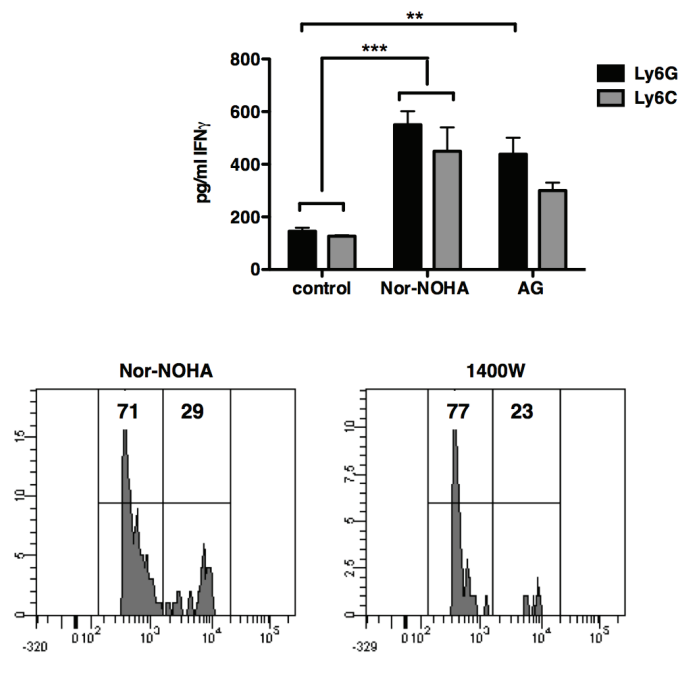

$\mathbf{E}$

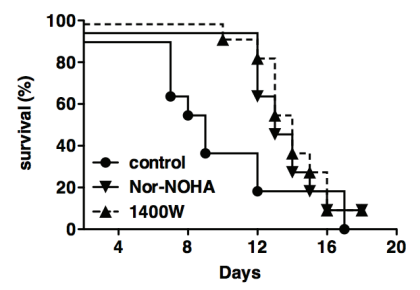

G

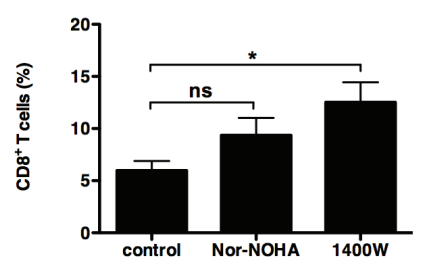

Figure 4: iNOS and arginase-1 can be used as targets to enhance cytotoxic T-cell responses. (A) Summarizing graph representing arg-1 expression by MDSC at the left and iNOS expression by MDSC at the right. (B) The graph on the left shows the proliferation inhibition of $\mathrm{CD} 3 / \mathrm{CD} 28$-activated $\mathrm{CD}^{+} \mathrm{T}$ cells with sorted in vitro MDSC (1:1 MDSC to $\mathrm{T}$ cell ratio). Control represents Cultures incubated without inhibitors. Cultures were supplemented with Nor-NOHA $(300 \mu \mathrm{M})$ or AG $(1 \mathrm{mM})$. The graph on the right shows changes in IFN- $\gamma$ secretion measured during the same experiment. Mean of at least 3 experiments $+/$ - SEM is shown in all graphs. (C) FACS graph showing the cytotoxic T-cell response against gp70 peptides of mice treated with Nor-NOHA, 1400W or PBS as a negative control. Number of mice per group $=3$. (D) Summarizing graph of panel C. (E) Overall survival of treated mice. Mice were sacrificed when tumor diameter reached $15 \mathrm{~mm}$. (F) Tumor growth curve of treated mice. Day 1 represents the first day of treatment, when tumor diameter reached approximately $6 \mathrm{~mm}$. (G) Graph summarizing the percentage of $\mathrm{CD} 8^{+} \mathrm{T}$ cells present in the tumor of treated mice. Values are normalized to CD45 and CD3. Experiments were performed twice and included 6 mice per group. Mean $+/-$ SEM is shown in all graphs. Number of asterisks in the figures indicates the level of statistical significance as follows: ${ }^{*}, p<0.05 ;{ }^{* *}, p<0.01 ;{ }^{* *}, p<0.001$. 
or iNOS, showed that the number of $\mathrm{CD}^{+} \mathrm{T}$ cells was enhanced in both treatment conditions (Fig. 3G). These data show that inhibition of arg-1 and iNOS resulted in higher numbers of functional $\mathrm{CD}^{+}$cytotoxic $\mathrm{T}$ cells, as predicted in the in vitro T-cell suppression assay using in vitro-generated CRC-specific MDSC.

\section{DISCUSSION}

GM-CSF is one of the most important factors produced by tumor cells leading to MDSC expansion. In literature, it is evident that GM-CSF plays an important role in the accumulation of $\operatorname{MDSC}[7,20,33]$. That is why current ex vivo MDSC differentiation protocols primarily rely on culturing bone marrow hematopoietic progenitors with recombinant GM-CSF. But clearly, other still unknown factors contribute to MDSC differentiation and expansion, as efficiency rarely surpasses $40 \%$, even with the addition of various other cytokines, such as IL-4, IL-13, PGE2, [21, 24, 26].

In this study, we demonstrated the feasibility of generating in vitro MDSC in a CRC model using the system described by Liechtenstein et al. in a melanoma model [28]. They reasoned that endogenous GM-CSF could have better differentiation efficiency as myelopoiesis within a tumor microenvironment was simulated. Obviously, this system does not mimic the complexity of the in vivo situation, but it may be a good practical approximation. Indeed, differentiation efficiency up to 90\% was achieved in our CRC model, while maintaining high proliferation capacity. Another advantages of this protocol compared to previously described methods are the high MDSC yields, which can not be obtained by merely supplementing CM of CT26 cells with recombinant GMCSF. Importantly, the high yield of pure CD11b cells obtained in this culture system circumvents the need to grow tumors and sacrifice a large number of mice to obtain sufficient tumor MDSC. Other advantages of the method presented in this manuscript, is its reproducibility and the ease at which this technique can be performed.

The one true accepted marker of MDSC is their suppressive capacity, as these cells otherwise display a great heterogeneity [34-37]. Our in vitro-generated CRCspecific MDSC are very potent immunosuppressive cells, demonstrated by their ability to suppress T cells, even at a 1:8 MDSC to $\mathrm{T}$ cell ratio. In addition, our data confirmed that the in vitro-generated CRC-specific MDSC are more similar to tumor MDSC than splenic MDSC. Therefore, this model would be more relevant in drug discovery studies than splenic MDSC. Spleen-derived MDSC are still widely used in MDSC research [38-43], despite the proof that these cells are very different indeed, both phenotypically as functionally [15].

The primary aim of the ex vivo MDSC generation protocol is to use these cells as a predictive tool for highthroughput screening in the search for new anti-MDSC drugs. However, its use is not restricted and they could be applied in a very broad manner. For example, Van der Jeught et al. used this ex vivo differentiation protocol to examine the modulation of the tumor microenvironment by using mRNA encoding soluble proteins [44].

In this study, we have shown that GM-CSF overexpression in vivo does initially not lead to changes in tumor volume, but does, amongst others, cause splenomegaly. Similar abnormalities were previously described in GM-CSF transgenic mice [45-47]. The increased number of myeloid cells in tumor and spleen is characterized by a CD $11 b^{+}$MDSC population and can be seen as an immune-inhibitory infiltrate [48]. These findings are consistent with the study performed by Bronte et al. who showed that a population of suppressive $\mathrm{CD} 1 \mathrm{~b}^{+} / \mathrm{Gr}-1^{+}$cells increased when tumor cells were modified to produce GM-CSF [33]. However, there is no clear consensus about the effects of chronic GM-CSF expression on tumor growth, as studies have shown either an anti-proliferative effect $[49,50]$, a tumor-promoting effect $[51,52]$ or no significant effect on tumor growth rate $[53,54]$. We showed no significant effects during the first 12 days of tumor growth. Long-lasting follow-up of tumor growth was impossible in our study, as the mice had to be sacrificed due to their splenomegaly, the latest at day 17. Nonetheless, we observed that the size of CT26GM-CSF tumors remained stable from day 12 onwards, whereas CT26 tumors continued to grow. To our surprise the lack of continued growth of CT26-GM-CSF tumors was not correlated to a tumor-specific T-cell response, suggesting that other mechanisms are responsible for the tumor control. Although, chronic GM-CSF expression was shown in some studies to lead to malignant progression of the tumor due to enhanced angiogenesis, invasiveness and migration [55-57], other studies showed that GMCSF production can also lead to improved survival in CRC [58]. GM-CSF has been studied for a while as a vaccine adjuvant in cancer immunotherapy due to its immunostimulatory properties [47, 59]. However, the results in clinical trials were disappointing in terms of immune responses and clinical outcome $[60,61]$. No link between GM-CSF-induced MDSC expansion and failure of GM-CSF in clinical trials has been demonstrated, but caution in this field is required as GM-CSF is much more then solely an immunostimulating cytokine.

Well-studied amino acid-consuming enzymes in MDSC biology are arg-1 and iNOS, both present on the two MDSC subtypes and important in conferring immunosuppressive capacities to these cells [7, 36]. As these molecules are important in the basis MDSC biology, we used them to further examine our in vitro-generated CRC-specific MDSC. Consistent with in vivo MDSC $[10,21,62]$, inhibiting arg-1 and iNOS directly affects their T-cell immunosuppressive activities. Furthermore, we inhibited arg-1 or iNOS intratumorally to examine whether we could observe similar effects in comparison 
to the in vitro system. To this end, we used the inhibitors Nor-NOHA and $1400 \mathrm{~W}$, respectively. AG was replaced with $1400 \mathrm{~W}$ to serve as the iNOS inhibitor during the in vivo study, since AG is a general NOS inhibitor, namely an inhibitor of iNOS but also endothelial NOS and neuronal NOS. The latter are not present in the in vitro culture, while 1400W specifically inhibits iNOS and is better suited for an in vivo setting. During treatment, a significant delay in tumor growth was observed and cytotoxic T-cell responses increased. In contrast, another study using a different arg1 inhibitor, namely $\mathrm{N}(\mathrm{G})$-nitro-L -arginine methyl ester (L-NAME), reported no increase in endogenous antitumor immunity [63]. Despite a significant increase in cytotoxic $\mathrm{T}$ cells, differences observed in $\mathrm{CD} 8^{+} \mathrm{T}$ cells were not as pronounced as anticipated. The lack hereof can probably be attributed to the experimental design. Treatment was ceased at day 10 and subsequent tumor growth might have allowed the "reconstitution" of the tumor environment. This experimental setup was chosen, as initially we were more interested in tumor development and overall survival. Another possibility is that inhibition of MDSC immunosuppressive activities may not alter the infiltration of immune cells (which would depend on cell trafficking), but rather their antitumor properties. We strongly believe that the immune signature of the tumor during treatment differs, as characterized by the increase in cytotoxic $\mathrm{T}$ lymphocytes during treatment. No inhibition in tumor growth was observed when similar experiments, in which arg-1 was inhibited, were performed in mice lacking functional T and B cells [64].This suggests that the growth delay of the tumor caused by the inhibition of arg-1 is at least partially dependent on the immune system. We are also aware that only one mechanism, either arg-1 or iNOS, is studied in this setting. Still, we can modulate the tumor environment leading to enhanced antitumor $\mathrm{T}$ cell responses. We believe that these T-cell responses could be further potentiated through combination therapy, ideally a mix of inhibitory (for example anti-MDSC drugs) and immunostimulatory molecules (for example vaccination).

The predictive value of in vitro MDSC still has to be examined further, but preliminary results already give a good indication about future possibilities of this ex vivo differentiation system.

\section{MATERIALS AND METHODS}

\section{Mice and cell lines}

Female, 6 to 8 weeks old Balb/c mice (Charles River Laboratories, L'Arbresle Cedex, France) were treated according to the European guidelines for animal experimentation. Experiments were reviewed by the Ethical Committee for use of laboratory animals of the Vrije Universiteit Brussel (Jette, Belgium). The mouse colon cancer cell line CT26 and mouse lymphoblast cell line FDCP-1 were obtained from the American Type Culture Collection (ATCC, Molsheim Cedex, France) and cultured according to the recommendations of ATCC.

\section{Production and characterization of lentiviral vectors encoding GM-CSF}

The packaging plasmid pCMV $\Delta$ R8.9 and VSV.G encoding plasmid pMD.G were a gift from Dr. D. Trono (University of Geneva). The plasmid encoding GM$\mathrm{CSF}$ and the puromycin resistance gene was previously described [28]. The production and characterization of lentiviral vectors was performed as described before [65].

\section{Transduction of CT26 cells with lentiviral vectors encoding GM-CSF}

Tumor cells, namely CT26, which over express GM-CSF, were generated by transduction with lentiviral vectors encoding for both mouse GM-CSF and the puromycin resistance gene. To that end $2 \times 10^{5}$ CT26 cells were plated in $2 \mathrm{ml}$ culture medium in a 6 -well. One day later, the culture medium was replaced with $2 \mathrm{ml}$ of the lentiviral transduction cocktail containing 15 infectious lentiviral particles per cell and $10 \mu \mathrm{g} / \mathrm{ml}$ protamine sulphate (Leo Pharma, Lier, Belgium). Three days later, transduced cells were selected using $3 \mu \mathrm{g} / \mathrm{ml}$ puromycin (Sigma-Aldrich, Diegem, Belgium). To collect conditioned medium (CM), cells were plated at $10 \times 10^{6}$ cells in $25 \mathrm{ml}$ culture medium in a $T 175 \mathrm{~cm}^{2}$ and kept in culture in the absence of puromycin for 3 days. To verify the production of GM-CSF, CM was used to culture FDCP-1 cells. To quantify the amount of GM-CSF, an ELISA (eBioScience, Vienna, Austria) was performed according to manufacturer's instructions.

\section{In vitro-differentiation of myeloid-derived suppressor cells}

Bone marrow cells were extracted from the femur and tibia of Balb/c mice, after which $10 \times 10^{6}$ bone marrow cells were cultured in 75\% CM and 25\% Iscove's Modified Dulbecco's medium (IMDM, Sigma-Aldrich) supplemented with $10 \%$ fetal clone I (FCI, GE Health Care Life Sciences, Hyclone Laboratories, Utah, USA), 100 U/ $\mathrm{ml}$ penicillin, $100 \mu \mathrm{g} / \mathrm{ml}$ streptomycin (Sigma-Aldrich) and $2 \mathrm{mM}$ L-glutamine (Sigma-Aldrich) for 6 days. Cell viability and cell numbers were evaluated by trypan blue staining (Sigma-Aldrich). To evaluate the morphology of the cells, $5 \times 10^{5}$ sorted MDSC were fixed on glass slides using the cytospin technique and were centrifuged at a speed of $1000 \mathrm{rpm}$ for 5 minutes. Cytospin slides, filter cards, sample chambers, and metal clips were all obtained 
from Thermo scientific (Massachusetts, USA). Cytospins were air dried for 2 hours and afterwards stained with hematoxylin and eosin.

\section{Isolation of in vivo differentiated myeloid-derived suppressor cells}

In order to grow tumors, Balb/c mice received a subcutaneous injection of $1 \times 10^{5} \mathrm{CT} 26$ tumor cells. When the tumor diameter exceeded $15 \mathrm{~mm}$, mice were sacrificed and single cell suspensions from the tumor and spleen were obtained as previously described [66]. To enrich $\mathrm{Ly}_{6 \mathrm{G}}{ }^{+}$or $\mathrm{Ly} 6 \mathrm{C}^{+} \mathrm{MDSC}$, we sorted the MDSC using the Myeloid-Derived Suppressor Cell Isolation Kit according to the manufacturer's instructions (Miltenyi Biotec, Bergisch-Gladbach, Germany).

\section{Cell staining and flow cytometry}

Staining of cell surface markers was performed as described [67]. The following antibodies were used: anti-CD11b-eF450, anti-MHC II-PE, anti-F4/80-APC-H7 (eBioScience), anti-CD11b-FITC, anti-Ly6G-AF647, anti-Ly6C-Pe-Cy7, anti-CD80-BV421, anti-PD-L1-PE, anti-CD3-PercP-Cy5.5, anti-CD11c-AF647 (Biolegend, London, United Kingdom), anti-Ly6G-PE-CF594, antiCD8-FITC (Becton Dickinson, Erembodegem, Belgium) and anti-CD45-VioBlue (130-102-775) (Mitenyi Biotec). For intracellular staining, cells were treated with inside FIX and incubated for 20 minutes at room temperature. Cells were incubated with PERM (Miltenyi Biotec) and the anti-arginase-1-PE (R\&D systems, Abingdon, United Kingdom) or anti-iNOS-PercP-Cy5.5 (Santa Cruz Biotechnology, Heidelberg, Germany) antibody for 20 minutes at room temperature. Subsequently, cells were washed. Cells stained with isotype matched control antibodies served as a control. Cells were acquired using the LSR Fortessa (Becton Dickinson) and analysis was performed using FlowJo 7.6 (Treestar Inc Oregon, United States of America).

\section{In vitro T-cell suppression assay}

To evaluate the suppressive activity of MDSC, we performed an in vitro T-cell suppression assay. To that end, $\mathrm{CD}^{+} \mathrm{T}$ lymphocytes were isolated from the spleen of Balb/c mice using the $\mathrm{CD} 8 \alpha^{+} \mathrm{T}$ cell Isolation Kit II (Miltenyi Biotec). These CD8 $\alpha^{+} \mathrm{T}$ lymphocytes were labeled with carboxyfluorescein diacetate succinimidyl ester (CFSE, Life Technologies, Gent, Belgium). First, cells were washed and suspended in $5 \mathrm{ml}$ phosphate buffered saline (PBS, Sigma-Aldrich) containing 0.1\% bovine serum albumin (BSA, Life Technologies). Five $\mathrm{ml}$ of 0.5 $\mu \mathrm{M}$ CFSE were added to the cell suspension. The single cell suspension was incubated at $37^{\circ} \mathrm{C}, 5 \% \mathrm{CO}_{2}$ for 10 minutes, washed in serum free Optimem (Invitrogen, Life Technologies), centrifuged for 7 minutes at $1500 \mathrm{rpm}$ and suspended in $5 \mathrm{ml}$ Optimem. Cells were plated at $1 \times 10^{5}$ cells in $100 \mu \mathrm{l}$ in a 96-well. Subsequently, the cells were either left unstimulated or were stimulated with a 1/800 dilution of anti-CD3/anti-CD28 coated beads (Invitrogen). Enriched $\mathrm{Ly}_{6 \mathrm{G}^{+}}$or $\mathrm{Ly} 6 \mathrm{C}^{+} \mathrm{MDSC}$ were obtained using the Myeloid-Derived Suppressor Cell Isolation Kit (Miltenyi Biotec). Sorted MDSC were added to the stimulated $\mathrm{T}$ cells at the indicated MDSC to $\mathrm{T}$ cell ratios. When indicated, specific inhibitors for arg-1 ( $\mathrm{N \omega}$-hydroxy-norArginine (Nor-NOHA), $300 \mu \mathrm{M})$ (Enzo Life Sciences, Antwerpen, Belgium) or iNOS (aminoguanidine (AG), 1 $\mathrm{mM}$ ) (Sigma-Aldrich) were added. Dilution of CFSE was evaluated 3 days later by flow cytometry as a measure of T-cell proliferation. To that end, T cells were additionally stained with anti-CD3-PercP-Cy5.5 (Biolegend). Data were collected using the FACSCanto Flow Cytometer (Becton Dickinson) and were analyzed with FlowJo 7.6 (Treestar Inc.). During the analysis, cells were gated according to their forward and side scatter distribution and to CD3 expression. Alternatively, supernatants were collected and screened for IFN- $\gamma$ content using a standard ELISA (Thermo scientific) according to manufacturer's instructions.

\section{Therapy}

$\mathrm{Balb} / \mathrm{c}$ mice received a subcutaneous injection of $1 \times 10^{5}$ CT26 tumor cells. When the tumors reached a diameter of $6 \mathrm{~mm}$, mice were treated for 10 consecutive days with an intratumoral injection of $50 \mu \mathrm{l}$ Nor-NOHA (80 mg/kg) (Enzo Life Sciences), 1400W hydrochloride $(20 \mathrm{mg} / \mathrm{kg})$ (Sigma- Aldrich) or PBS. The tumor volume was measured on a daily basis using a caliper. Mice were sacrificed by neck dislocation when the tumor diameter exceeded $15 \mathrm{~mm}$.

\section{In vivo cytotoxicity assay}

An in vivo cytotoxicity assay was performed after 5 consecutive treatments with Nor-NOHA, 1400W or PBS (see above) to evaluate the stimulation of cytotoxic antitumor immune responses. The assay was performed as described by Van Lint et al. [68] using gp70 peptide (Thermo Electron GmbH, Ulm, Germany) pulsed cells as targets.

\section{ELISPOT}

Lymph nodes (LN) and spleens were isolated and single cell suspensions were prepared as described before by Goyvaerts et al. [66]. Enzyme-linked immunospot 
(ELISPOT) plates (Millipore, Brussels, Belgium) were coated with $100 \mu \mathrm{l}$ purified anti-IFN- $\gamma$ antibodies and incubated overnight at $4{ }^{\circ} \mathrm{C}$. Wells were then blocked with $100 \mu \mathrm{l}$ blocking buffer (RPMI supplemented with $10 \%$ FCI). A total of $1 \times 10^{5}$ MACS sorted CD $8^{+}$splenocytes (Miltenyi Biotec.) or $2 \times 10^{5}$ unsorted LN cells were plated per well (in duplicate). Cells were either left unstimulated and served as a negative control or cells were treated with gp70 peptide. Concanavalin A (Sigma- Aldrich) stimulated $\mathrm{T}$ cells served as a positive control. ELISPOT plates were incubated at $37^{\circ} \mathrm{C}, 5 \% \mathrm{CO}$ for $24 \mathrm{~h}$. Next, the ELISPOT plates were developed according to the manufacturer's instructions (Diaclone, Besançon, France). Spots were counted using an ELISPOT counter (Autoimmun Diagnostika GmbH, Straßberg, Germany) and software (Autoimmun Diagnostika ELISPOT Reader 5.0).

\section{Statistical analyses}

A t-test and a one-way ANOVA followed by a Bonferroni's multiple comparison test was performed. Sample sizes and number of times experiments were repeated are indicated in the figure legends. Number of asterisks in the figures indicates the level of statistical significance as follows: *, $p<0.05 ;{ }^{* *}, p<0.01 ; * *, p<$ 0.001 . The results are shown in column graphs as the mean \pm standard error of the mean (SEM). Survival of mice in the therapy experiment was visualized in a Kaplan-Meier plot. Differences in survival were analyzed by the log-rank test. All data were analyzed using GraphPad Prism 5.

\section{ACKNOWLEDGEMENTS}

We thank Ka Lun Law and Angelo Willems for their technical assistance.

This work was supported by grants from the Interuniversity Attraction Poles Program-Belgian StateBelgian Science Policy, the National Cancer Plan of the Federal Ministry of Health, the "Stichting tegen Kanker", the "Vlaamse Liga tegen Kanker", an Integrated Project and EU FP7-funded Network of Excellence, an IWTTBM program, the "FWO-Vlaanderen", the Scientific Fund Willy Gepts of the University Hospital Brussels. ID is funded by the IWT. TL is funded by a University College London Overseas PhD Scholarship. WL is funded by Scientific Fund Willy Gepts of the University Hospital Brussels. DE has been funded by an Arthritis Research UK Career Development Fellowship (18433) and currently by a Miguel Servet Fellowship from the Instituto de Salud Carlos III, Spain. MDR is funded by the VLK.

David Escors and Therese Liechtenstein are inventors of the MDSC production method (European patent 14166221.3-1405).

\section{CONFLICTS OF INTEREST}

We declare that all authors participated in the proposed work and that this manuscript is not under consideration for review elsewhere. The contents of this manuscript will not be copyright, submitted or published elsewhere while acceptance by Oncotarget is under consideration. David Escors and Therese Liechtenstein are inventors of the MDSC production method (European patent 14166221.3-1405). The other authors declare no potential conflicts of interest.

\section{REFERENCES}

1. Pagès F, Berger A, Camus M, Sanchez-Cabo F, Costes Anne, Molidor R, Mlecnik B, Kirilovsky A, Nilsson M, Damotte D, Meatchi T, Bruneval P, Cugnenc P et al. Effector memory $\mathrm{T}$ cells, early metastasis, and survival in colorectal cancer. N Engl J Med. 2005; 353: 2654-66.

2. Galon J, Costes A, Sanchez-Cabo F, Kirilovsky A, Mlecnik $\mathrm{B}$, Lagorce-Pagès $\mathrm{C}$, Tosolini $\mathrm{M}$, Camus $\mathrm{M}$, Berger $\mathrm{A}$, Wind $\mathrm{P}$, Zinzindohoué F, Bruneval $\mathrm{P}$, Cugnenc $\mathrm{P}$ et al. Type, density, and location of immune cells within human colorectal tumors predict clinical outcome. Science. 2006; 313: 1960-64.

3. Tosolini M, Kirilovsky A, Mlecnik B, Fredriksen T, Mauger S, Bindea G, Berger A, Bruneval P, Fridman W, Pagès $\mathrm{F}$ and Galon J. Clinical impact of different classes of infiltrating T cytotoxic and helper cells (Th1, Th2, Treg, Th17) in Patients with colorectal Cancer. Cancer Res. 2011; 71: 1263-71.

4. Zhang B, Wang Z, Wu L, Zhang M, Li W, Ding J, Zhu J, Wei $\mathrm{H}$ and Zhao K. Circulating and tumor-infiltrating myeloid-derived suppressor cells in patients with colorectal carcinoma. PLoS ONE. 2013; 8: e57114.

5. Sermeus A, Leonard W, Engels B and De Ridder M. Advances in radiotherapy and targeted therapies for rectal cancer. World J Gastroenterol. 2014; 20: 1-5.

6. Lechner MG, Karimi SS, Barry-Holson K, Angell TE, Murphy KA, Church CH, Ohlfest JR, Hu P and Epstein AL. Immunogenicity of murine solid tumor models as a defining feature of in vivo behavior and response to immunotherapy. J Immunother. 2013; 36: 477-89.

7. Gabrilovich DI and Nagaraj S. Myeloid-derived suppressor cells as regulators of the immune system. Nat Rev Immunol. 2009; 9: 162-74.

8. Lechner MG, Liebertz DJ and Epstein AL. Characterization of cytokine-induced myeloid-derived suppressor cells from normal human peripheral blood mononuclear cells. J Immunol. 2010; 185: 2273-84.

9. Talmadge JE. Pathways mediating the expansion and immunosuppressive activity of myeloid-derived suppressor cells and their relevance to cancer therapy. Clin Cancer Res. 2007; 13: 5243-48. 
10. Gabrilovich DI, Ostrand-Rosenberg S and Bronte V. Coordinated regulation of myeloid cells by tumours. Nat Rev Immunol. 2012; 12: 253-68.

11. Vincent J, Mignot G, Chalmin F, Ladoire S, Bruchard M, Chevriaux A, Martin F, Apetoh L, Rébé C and Ghiringhelli F. 5-Fluorouracil selectively kills tumor-associated myeloid-derived suppressor cells resulting in enhanced $\mathrm{T}$ cell-dependent antitumor immunity. Cancer Res. 2010; 70: 3052-61.

12. Suzuki E, Kapoor V, Jassar AS, Kaiser LR and Albelda SM. Gemcitabine selectively eliminates splenic $\mathrm{Gr}-1+/$ $\mathrm{CD} 11 \mathrm{~b}+$ myeloid suppressor cells in tumor-bearing animals and enhances antitumor immune activity. Clin Cancer Res. 2005; 11: 6713-21.

13. Le HK, Graham L, Cha E, Morales JK and Bear HD. Gemcitabine directly inhibits myeloid derived suppressor cells in BALB/c mice bearing 4T1 mammary carcinoma and augments expansion of $\mathrm{T}$ cells from tumor-bearing mice. Int Immunopharmacol. 2009; 9: 900-09.

14. Kodumudi KN, Woan K, Gilvary DL, Sahakian E, Wei S and Djeu JY. A novel chemoimmunomodulating property of docetaxel: suppression of myeloid-derived suppressor cells in tumor bearers. Clin Cancer Res. 2010; 16: 4583-94.

15. Maenhout SK, Van Lint S, Emeagi PU, Thielemans K and Aerts JL. Enhanced suppressive capacity of tumorinfiltrating myeloid-derived suppressor cells compared with their peripheral counterparts. Int J Cancer. 2014; 134: 1077 90.

16. Corzo CA, Condamine T, Lu L, Cotter MJ, Youn J, Cheng P, Cho H, Celis E, Quiceno DG, Padhya T, McCaffery TV, McCaffrey JC and Gabrilovich D. HIF-1 regulates function and differentiation of myeloid-derived suppressor cells in the tumor microenvironment. J Exp Med. 2010; 207: 243953.

17. Thaci B, Ahmed AU, Ulasov IV, Wainwright DA, Nigam P, Auffinger B, Tobias AL, Han Y, Zhang L, Moon KS and Lesniak MS. Depletion of myeloid-derived suppressor cells during interleukin-12 immunogene therapy does not confer a survival advantage in experimental malignant glioma. Cancer Gene Ther. 2014; 21: 38-44.

18. Apolloni E, Bronte V, Mazzoni A, Serafini P, Cabrelle A, Segal DM, Young A and Zanovello P. Immortalized myeloid suppressor cells trigger apoptosis in antigenactivated T lymphocytes. J Immunol. 2000; 165: 6723-30.

19. Lutz M, Kukutsch N, Menges M, Rössner S and Schuler G. Culture of bone marrow cells in GM-CSF plus high doses of lipopolysaccharide generates exclusively immature dendritic cells which induce alloantigen- specific CD4 T cell anergy in vitro. Eur J Immunol. 2000; 30: 1048-52.

20. Morales JK, Kmieciak M, Knutson KL, Bear HD and Manjili MH. GM-CSF is one of the main breast tumorderived soluble factors involved in the differentiation of CD11b-Gr1- bone marrow progenitor cells into myeloidderived suppressor cells. Breast Cancer Res Treat. 2009; 123: 39-49.
21. Youn J-I, Nagaraj S, Collazo $M$ and Gabrilovich DI. Subsets of myeloid-derived suppressor cells in tumorbearing mice. J Immunol. 2008; 181: 5791-802.

22. Marigo I, Bosio E, Solito S, Mesa C, Fernandez A, Dolcetti L, Ugel S, Sonda N, Bicciato S, Falisi E, Calabrese F, Basso $\mathrm{G}$, Zanovello $\mathrm{P}$ et al. Tumor-induced tolerance and immune suppression depend on the C/EBPbeta transcription Factor. Immunity. 2010; 32: 790-802.

23. Zhou Z, French DL, Ma G, Eisenstein S, Cheng Y, Divino CM, Keller G, Chen S and Pan P. Development and function of myeloid-derived suppressor cells generated from mouse embryonic and hematopoietic stem cells. Stem Cells. 2010; 28: 620-32.

24. Obermajer $\mathrm{N}$ and Kalinski P. Generation of myeloidderived suppressor cells using prostaglandin E2. Transplant Res. 2012; 1: 15.

25. Xiang X, Poliakov A, Liu C, Liu Y, Deng Z, Wang J, Cheng Z, Shah SV, Wang G, Zhang L, Grizzle WE, Mobley J and Zhang H. Induction of myeloid-derived suppressor cells by tumor exosomes. Int J Cancer. 2008; 124: 2621-33.

26. Highfill SL, Rodriguez PC, Zhou Q, Goetz CA, Koehn BH, Veenstra R, taylor PA, Panoskaltsis-Mortari A, Serody JS, Munn DV, Tolar J, Ochoa AC and Blazer BR. Bone marrow myeloid-derived suppressor cells (MDSCs) inhibit graftversus-host disease (GVHD) via an arginase-1-dependent mechanism that is up-regulated by interleukin-13. Blood. 2010; 116: 5738-47.

27. Escors D, Liechtenstein T, Perez-Janices N, Schwarze J, Dufait I, Goyvaerts C, Lanna A, Arce F, BlancoLuquin I, Kochan G, Guerrero-Setas D and Breckpot K. Assessing T-cell responses in anticancer immunotherapy: Dendritic cells or myeloid-derived suppressor cells? Oncoimmunology. 2013; 2: e26148.

28. Liechtenstein T, Perez-Janices N, Gato M Caliendo F, Kochan G, Blanco-Luquin A, Van Der Jeught K, Arce F, Guerrero-Setas D, Fernandez-Irigoyen J, Santamari

E, Breckpot K and Escors D. A highly efficient tumorinfiltrating MDSC differentiation system for discovery of anti-neoplastic targets, which circumvents the need for tumor establishment in mice. Oncotarget. 2014; 5: 7843-57.

29. Solito S, Falisi E, Diaz-Montero CM, Doni A, Pinton L, Rosata A, Francescato S, Basso G, Zanovello P, Onicescu G, Garrett-Mayer E, Montero AJ, Bronte V et al. A human promyelocytic-like population is responsible for the immune suppression mediated by myeloid-derived suppressor cells. Blood. 2011; 118: 2254-65.

30. Sun HL, Zhou X, Xue YF, Wang K, Shen Y, Mao J, Guo H and Miao Z. Increased frequency and clinical significance of myeloid-derived suppressor cells in human colorectal carcinoma. World J Gastroenterol. 2012; 18: 3303-09.

31. Choi J, Suh B, Ahn YO, Kim TM, Lee JO, Lee SH and Heo DS. CD15+/CD16low human granulocytes from terminal cancer patients: granulocytic myeloid-derived suppressor cells that have suppressive function. Tumor Biol. 2011; 33: 121-29. 
32. Kusmartsev S, Nagaraj S and Gabrilovich DI. Tumorassociated CD8 + T cell tolerance induced by bone marrowderived immature myeloid cells. J Immunol. 2005; 175: 4583-92.

33. Bronte V, Chappell DB, Apolloni E, Cabrelle A, Wang M, Hwu P and Restifo NP. Unopposed production of granulocyte-macrophage colony-stimulating factor by tumors inhibits CD8+ T cell responses by dysregulating antigen-presenting cell maturation. J Immunol. 1999; 162: 5728-37.

34. Gabrilovich DI, Bronte V, Chen SH, Colombo MP, Ochoa A, Ostrand-Rosenberg S and Schreiber H. The terminology issue for myeloid-derived suppressor cells. Cancer Res. 2007; 67: 425.

35. Ostrand-Rosenberg S and Sinha P. Myeloid-derived suppressor cells: linking inflammation and cancer. J Immunol. 2009; 182: 4499-506.

36. Serafini P, Borrello I and Bronte V. Myeloid suppressor cells in cancer: Recruitment, phenotype, properties, and mechanisms of immune suppression. Seminars in Cancer Biology. 2006; 16: 53-65.

37. Ribechini E, Greifenberg V, Sandwick S and Lutz MB. Subsets, expansion and activation of myeloid-derived suppressor cells. Med Microbiol Immunol. 2010; 199: 273-81.

38. Zheng Y, Xu M, Li X, Jia J, Fan K and Lai G. Cimetidine suppresses lung tumor growth in mice through proapoptosis of myeloid-derived suppressor cells. Mol Immunol. 2013; 54: 74-83.

39. Mao Y, Sarhan D, Steven A, Seliger B, kiessling R and Lundqvist A. Inhibition of tumor-derived prostaglandin-E2 blocks the induction of myeloid-derived suppressor cells and recovers natural killer cell activity. Clin Cancer Res. 2014; 20: 4096-106.

40. Mikysková R, Indrová M, Vlková V, Bieblová J, Simová J, Paracková Z, Pajtasz-Piasecka E, Rossowskai J and Reinis M. DNA demethylating agent 5-azacytidine inhibits myeloid-derived suppressor cells induced by tumor growth and cyclophosphamide treatment. J Leukoc Biol. 2014; 95: 743- 53.

41. Alizadeh D, Trad M, Hanke NT, Larmonier CB, Janikashvill N, Bonnotte B, Katsanis E and Larmonier N. Doxorubicin eliminates myeloid-derived suppressor cells and enhances the efficacy of adoptive T-cell transfer in breast cancer. Cancer Res. 2014; 74: 104-18.

42. Chakraborty P, Das S, Banerjee K, Sinha A, Roy S, Chatterjee $M$ and Choudhuri SK. A copper chelate selectively triggers apoptosis in myeloid-derived suppressor cells in a drug-resistant tumor model and enhances antitumor immune response. Immunopharmacol Immunotoxicol. 2014; 36: 165-75.

43. Peranzoni E, Zilio S, Marigo I, Dolcetti L, Zanovello P, Mandruzzato S and Bronte V. Myeloid-derived suppressor cell heterogeneity and subset definition. Curr Opin
Immunol. 2010; 22: 238-44.

44. Van der Jeught K, Tjok Joe P, Bialkowski L, Heirman C, Daszkiewicz L, Liechtenstein T, Escors D, Thielemans K and Breckpot $\mathrm{K}$. Intratumoral administration of mRNA encoding a fusokine consisting of IFN- $\beta$ and the ectodomain of the TGF- $\beta$ receptor II potentiates antitumor immunity. Oncotarget. 2014; 5: 10100-13.

45. Burke B, Pridmore A, Harraghy N, Collick A, Brown J and Mitchell T. Transgenic mice showing inflammationinducible overexpression of granulocyte macrophage colony-stimulating factor. Clin Diagn Lab Immunol. 2004; 11: 588-98.

46. Lang RA, Metcalf D, Cuthbertson RA, Lyons I, Stanley E, Kelso A, Kannourakis G, Williamson DJ, Klinthworth GK and Gonda TJ. Transgenic mice expressing a hemopoietic growth factor gene (GM-CSF) develop accumulations of macrophages, blindness, and a fatal syndrome of tissue damage. Cell. 1987; 51: 675-86.

47. Dranoff G, Jaffee E, Lazenby A, Golumbek P, Levitsky H, Brose K, Jackson V, Hamada H, Pardoll D and Mulligan RC. Vaccination with irradiated tumor cells engineered to secrete murine granulocyte-macrophage colony-stimulating factor stimulates potent, specific, and long-lasting antitumor immunity. Proc Natl Acad Sci USA. 1993; 90: 353943.

48. Lesokhin AM, Hohl TM, Kitano S, Cortez C, HirschhornCymerman D, Avogadri F, Rizzuto GA, Lazarus JJ, Pamer EG, Houghton AN, Merghoub $\mathrm{T}$ and Wolchok JD. Monocytic CCR2+ myeloid-derived suppressor cells promote immune escape by limiting activated CD8 T-cell infiltration into the tumor microenvironment. Cancer Res. 2012; 72: 876-86.

49. Ruff MR, Farrar WL and Pert CB. Interferon gamma and granulocyte/macrophage colony-stimulating factor inhibit growth and induce antigens characteristic of myeloid differentiation in small-cell lung cancer cell lines. Proc Natl Acad Sci USA. 1986; 83: 6613-17.

50. Yamashita Y, Nara N and Aoki N. Antiproliferative and differentiative effect of granulocyte-macrophage colonystimulating factor on a variant human small cell lung cancer cell line. Cancer Res. 1989; 49: 5334-8.

51. Berdel WE, Danhauser-Riedl S, Steinhauser G and Winton EF. Various human hematopoietic growth factors (interleukin-3, GM-CSF, G-CSF) stimulate clonal growth of nonhematopoietic tumor cells. Blood. 1989; 73: 80-83.

52. Dedhar S, Gaboury L, Galloway P and Eaves C. Human granulocyte-macrophage colony-stimulating factor is a growth factor active on a variety of cell types of nonhemopoietic origin. Proc Natl Acad Sci USA. 1988; 85: 9253-57.

53. Berdel WE, Zafferani M, Senekowitsch R, Kreuser ED and Thiel E. Effect of interleukin-3 and granulocytemacrophage colony-stimulating factor on growth of xenotransplanted human tumour cell lines in nude mice. Eur J Cancer. 1992; 28-377-80. 
54. Foulke RS, Marshall MH, Trotta PP and Von Hoff DD. In vitro assessment of the effects of granulocyte-macrophage colony-stimulating factor on primary human tumors and derived lines. Cancer Res. 1990; 50: 6264-67.

55. Obermueller E, Vosseler S, Fusenig NE and Mueller MM. Cooperative autocrine and paracrine functions of granulocyte colony-stimulating factor and granulocytemacrophage colony-stimulating factor in the progression of skin carcinoma cells. Cancer Res. 2001; 64: 7801-12.

56. Gutschalk CM, Herold-Mende CC, Fusening NE and Mueller MM. Granulocyte Colony-Stimulating Factor and Granulocyte-Macrophage Colony-Stimulating Factor Promote Malignant Growth of Cells from Head and Neck Squamous Cell Carcinomas In vivo. Cancer Res. 2006; 66: 8026-36.

57. Gutschalk CM, Yanamandra AK, Linde N, Meides A, Depner S and Mueller MM. GM-CSF enhances tumor invasion by elevated MMP-2, -9, and -26 expression. Cancer Med. 2012; 2: 117-29.

58. Nebiker C, Han J, Eppenberger-Castori S, Iezzi G, Amicarella F, Cremonesi E, Huber X, Padovan E, Angrisani B, Droeser RA, Rosso R, Bolli M, Oertli D et al. GM-CSF production by tumor cells is associated with improved survival in colorectal cancer. Clin Cancer Res. 2014; 20: 3094-106.

59. Le DT, Pardoll DM and Jaffee EM. Cellular vaccine approaches. Cancer Journal. 2010; 16: 304-10.

60. Faries MB, Hsueh EC, Ye X, Hoban M and Morton DL. Effect of granulocyte/macrophage colony-stimulating factor on vaccination with an allogeneic whole-cell melanoma vaccine. Clin Cancer Res. 2009; 15: 7029-35.

61. Slingluff CL, Petroni GR, Olson WC, Smolkin ME, Ross MI, Haas NB, Grosh WW, Boisvert ME, Kirkwood JM and Chianese-Bullock KA. Effect of granulocyte/macrophage colony-stimulating factor on circulating CD8+ and CD4+ $\mathrm{T}$-cell responses to a multipeptide melanoma vaccine: outcome of a multicenter randomized trial. Clin Cancer Res. 2009; 15: 7036-44.

62. Jayaraman P, Alfarano MG, Svider PF, Parikh F, Lu G, Xiong $\mathrm{H}$ and Sikora AG. iNOS expression in CD4+ T cells limits T-reg induction by repressing TGFb-1: combined iNOS inhibition and T-reg depletion unmask endogenous anti-tumor immunity. Clin Cancer Res. 2014; 20(23).

63. Rigamonti N, Capuano G, Ricupito A, Jachetti E, Grioni M, Generoso L, Freschi M and Bellone M. Modulators of arginine metabolism do not impact on peripheral $\mathrm{T}$-cell tolerance and disease progression in a model of spontaneous prostate cancer. Clin Cancer Res. 2011; 17: 1012-23.

64. Rodriguez PC, Ernstoff MS, Hernandez C Atkins M, Zabaleta J, Sierra R and Ochoa AC. Arginase I-producing myeloid-derived suppressor cells in renal cell carcinoma are a subpopulation of activated granulocytes. Cancer Res. 2009; 69: 1553-60.

65. Goyvaerts C, De Groeve K, Dingemans J, Van Lint S,
Robays L, Heirman C, Reiser J, Zhang XY, De Baestelier P, Raes G and Breckpot K. Development of the Nanobody display technology to target lentiviral vectors to antigenpresenting cells. Gene Therapy. 2012; 19: 1133-40.

66. Emeagi PU, Thielemans $\mathrm{K}$ and Breckpot $\mathrm{K}$. The role of SMAC mimetics in regulation of tumor cell death and immunity. Oncoimmunology. 2012; 1: 965-67.

67. Breckpot K, Dullaers M, Bonehill A, Meirvenne SV, Heirman C, Greef CD, Van der bruggen P and Thielemans K. Lentivirally transduced dendritic cells as a tool for cancer immunotherapy. J Gene Med. 2003; 5: 654-67.

68. Van Lint S, Goyvaerts C, Maenhout S, Goethals L, Disy A, Benteyn D, Pen J, Bonehill A, Heirman C, Breckpot K and Thielemans K. Preclinical evaluation of triMix and antigen mRNA-based antitumor therapy. Cancer Res. 2012; 72: 1661-71. 